\title{
Housing Locational Choice Implications Of Rapid Transit Expenditures
}

\author{
Sid Davis*
}

\section{INTRODUCTION}

The focus of this analysis is to explore the way transportation expenditures influence household locational choice. In order to accomplish this primary objective, it is first necessary to outline some general behavioral assumptions concerning the way in which households satisfy their need for the flow of service that is derived from combining a particular structure with a specific site within an urban community, keeping in mind the importance of transportation as a crucial ingredient in facilitating interaction between the household and the rest of the community.

\section{RATIONALE FOR INVESTIGATION}

For many years transportation planning meant highway planning. While there is a wide variety of reasons for this narrow focus on a specific mode, it seems clear that (1) funding arrangements for highways at the federal level [16] through a trust fund, (2) rising household incomes which provided the purchasing power to acquire autos, (3) improvements in industrial and communications technology, along with (4) social and institutional considerations, were mutually reinforcing factors that stimulated highway investment as well as rapid activity decentralization. While we may be impressed by the recent pace and extent of this dispersal, Edwin Mills [9] points out in an easily understood way, that these forces have been at work for a long time, leading to a generally massive and pervasive suburbanization of metropolitan areas in the United States. ${ }^{1}$

For a significant portion of the post World War II period support for transit directly from the public through patronage or through government as agent of public interest was minimal. In 1945, for example, total passenger volume was 23.3 billion. By 1970 this volume had declined to slightly more than 7 billion passengers. Interrelated to this decline in passengers was a shrinkage of the vehicle miles operated from 3.3 billion in 1945 to under 1.9 billion in 1970, with a fourfold increase in fares [2]. During the same period, federal expenditures to finance public transit industry infrastructure were so small as to be virtually nonexistent. In 1965, for example, grant-in-aid to state and local govern-

\footnotetext{
*Associate Professor, School of Business Administration, Atlanta University.
} 
ments for urban transit amounted to $\$ 11$ million compared to slightly more than $\$ 4$ billion for highways. To make the comparison between relative levels of investments in the two modes more vivid, we have only to look at the approximately $\$ 300$ million in federal aid for urban transit in 1973, constituting probably 80 percent of all governmental expenditures to support transit, in relationship to the $\$ 21.6$ billion spent on highways, to realize the enormous difference in public investment policy.

While the general features of this public expenditure array for transportation still exist, there have been notable shifts in the last five years toward improving the quality of transit service available, especially in major metropolitan areas. The federal legislative base for these transit improvements was established by the Urban Mass Transportation Assistance Act of 1970 [17], which committed $\$ 10$ billion over a ten-year period primarily for capital grants to communities on a $2 / 3$ federal/ $1 / 3$ local share arrangement. Subsequent legislation increased the amount of capital grant-in-aid available as well as reduced local matching share requirements. Much of the impetus to develop federal support for transit grant-in-aid programs came from communities that were developing a broader public awareness of environmental as well as social and political issues related to highways. These issues arose from the continued accommodation of private auto tripmaking through the construction of highway networks that reduced or moderated the cost of travel. San Francisco initiated early development of a transit program emphasizing rail line haul facilities without federal aid. Other cities like Atlanta needed the promise of federal cost sharing in order to get positive response to a bond referendum raising the local funds to support a large scale rail transit development program. The estimated capital cost for the Atlanta system at referendum time was $\$ 1.4$ billion. Its current cost is estimated in excess of $\$ 2.1$ billion.

\section{Transportation and Activity Location}

While the required environmental impact statement prepared on the Atlanta project [15] discussed a number of factors of great importancefor example, noise and air pollution as well as direct transportation related impacts-it paid particular attention to the activity locational consequences of transit. The report states that:

- there are a number of economic impacts of transit which extend beyond the transportation system. In particular, location of future activities is affected by the significant changes in the regional pattern of accessibility which a transit system introduces. The transit system provides the greatest economic gains in the central portion of the region, high intensity activity areas and in the immediate vicinity of station areas. The effect of transit, operating through the land market, will be to cause residential and commercial activities to cluster in station areas at significantly higher densities that are typical of the Atlanta region. ${ }^{2}$ 
The emphasis on transportation's impact upon activity location has firm theoretical underpinnings developed in the works of Ricardo and Van Thunen and in extensions by the theoretical and empirical research done by a number of persons including William Alonso [1], Richard Muth [11], Edwin Mills [9,10] and Malcolm Getz [6,7]. While there is widespread acknowledgement of the interaction between transportation and land use, there are not necessarily the same perspectives on the direction and extent of these impacts nor an emphasis on the same array of consequences. Mills concludes that commuter transportation improvements may increase CBD employment slightly but that the overall effect will be to flatten the urban area's population density function. ${ }^{3}$ Getz points out "... that improvements in commuter transportation to a node will tend to increase the level of economic activity at that node relative to other nodes; that enlargement of a particular node will tend to increase average trip lengths; and that enhancement of growth at a central node will retard suburbanization." ${ }^{4}$ While these two researchers emphasize several different location consequences, they do point out issues which are either (1) neglected in the Atlanta system's final environmental impact statement's discussion of locational consequences of improved transit, or (2) are different, by implication, from the statement's assessment of the size of impact. The EIS (environmental impact statement) neglects completely a discussion of the issue of the possibility of general activity dispersal caused by reducing commuter costs and chooses to emphasize possible central area and station area density gains from the proposed transit improvements.

\section{Focus of Research}

The model and empirical analysis being presented in this paper are in part a response to these and related activity locational issues which flow out of the public investments in transit being undertaken in Atlanta. The focus of the analysis is narrow, in that it deals with household residential choice rather than locational choice for all major activity components. It is also aggregative in the sense that it attempts to provide insight in the general direction of consumer behavior, but disaggregated to the extent that the general examination of household locational choice is stratified by income class.

\section{Hypothesis}

There are two general locational questions that are addressed. The first deals directly with household locational behavioral response to improvements in transit; the second deals with the recognition that while transit access is being improved, several other crucial determinants of locational behavior are also changing. These are income, rents, auto ownership and employment location. It seems reasonable that the historic trend in the size of these locational determinants has worked to 
reinforce household suburbanization, offsetting whatever density reinforcing effects transit may have (assuming there is any at all).

\section{THEORETICAL FRAMEWORK}

The general theoretical framework that is used is based on standard microeconomic concepts beginning with utility maximization. The household, which is the consuming unit in this analysis, is considered to be consuming housing service flows which represent the utility derived from a dwelling unit that has a specific spatial location within the community and a specific vector of physical attributes in combination with a quantity of transportation.

Let us consider, by way of example, that the household maximized its utility by consuming $Q$, which represents a bundle of service flows from a composite housing good, and by consuming X, representing all other goods and services. We can express the consumer utility function in the conventional manner:

(1) $\mathrm{U}=\mathrm{U}(\mathrm{Q}, \mathrm{X})$

which is subject to a budget constraint:

(2) $\mathrm{Y}=\mathrm{P}_{\mathrm{q}} \mathrm{Q}+\mathrm{P}_{\mathrm{x}} \mathrm{X}$

Where:

$\mathrm{Y}=$ household budget

$\mathrm{P}_{\mathrm{q}}=$ price per unit of good $\mathrm{Q}$

$\mathrm{P}_{\mathrm{x}}=$ price per unit of good $\mathrm{X}$

If we consider, however, that the household is both the producer and consumer of $\mathrm{Q}$, the composite housing good, then it is possible to write a household consumption/production function as follows:

(3) $\mathrm{Q}=\mathrm{Q}(\mathrm{H}, \mathrm{L}, \mathrm{T})$

Where:

$\mathrm{Q}=$ composite housing good

$\mathrm{H}=$ non-locational specific housing good

$\mathrm{L}=$ locational specific housing good

$\mathrm{T}=$ transportation

subject to an expenditure constraint:

(4) $\mathrm{Y}_{\mathrm{q}}=\mathrm{P}_{\mathrm{h}} \mathrm{H}+\mathrm{P}_{\mathrm{l}} \mathrm{L}+\mathrm{P}_{\mathrm{t}} \mathrm{T}$

Where:

$\mathrm{Y}_{\mathrm{q}}=$ budget allocation for good $\mathrm{Q}$

$\mathrm{P}_{\mathrm{h}}=$ price of the non-locational specific housing good

$\mathrm{P}_{1}=$ price of the locational specific housing good

$\mathrm{P}_{\mathrm{t}}=$ price of transportation 
An important aspect of this particular treatment of locational theory is provided in equation 3. Aside from examining the generation of housing service flows, it separates the "factors" used in producing these flows into three inputs: the non-locational housing good $(\mathrm{H})$, which includes the physical attributes of the housing unit such as its quality, age, and lot size; the locational specific housing good (L), which positions the non-locational housing good $(\mathrm{H})$ spatially within the urban area; and transportation $(\mathrm{T})$, a commodity which is used to overcome the frictions of time and space as households seek to participate in activities taking place in locations removed from the place of residence.

\section{Development of Estimatable Model}

The functional relationship between housing service flows and their determinants has been expressed as:

(5) $\mathrm{Q}=\mathrm{Q}(\mathrm{H}, \mathrm{L}, \mathrm{T})$

It is now possible to explore the following relationships:

(6) $\mathrm{H}_{\mathrm{k}}=\mathrm{H}_{\mathrm{k}}\left(\mathrm{L}, \mathrm{T}, \mathrm{X}-\mathrm{X}_{\mathrm{n}}\right)$

(7) $\mathrm{L}_{\mathrm{k}}=\mathrm{L}_{\mathrm{k}}\left(\mathrm{H}, \mathrm{T}, \mathrm{X},-\mathrm{X}_{\mathrm{n}}\right)$

(8) $\mathrm{T}_{\mathrm{k}}=\mathrm{T}_{\mathrm{k}}\left(\mathrm{L}, \mathrm{H}, \mathrm{X},-\mathrm{X}_{\mathrm{n}}\right)$

A major implication contained in equations 6,7 and 8 is the simultaneous household decision making that appears. The amount of the non-locational housing good $(\mathrm{H})$ is a function of the locational housing good $(\mathrm{L})$ and amount of transportation ( $\mathrm{T}$ ) used. This seems logical in view of the previous considerations of the household's making a budget allocation from income for housing service flows and because the amount of $\mathrm{H}$ used depends on $\mathrm{L}$ and $\mathrm{T}$, given tastes and prices. Another important implication of these equations is the stratification of the model into $\mathrm{k}$ income classes which carries with it the $a$ priori assumption that different income groups have significant income related behaviorial differences in the way they satisfy their need for housing service flows. ${ }^{5}$

Empirical evaluation of the theoretical modification provided in this study is possible by appropriate model specification and the development of the necessary structural equations. Since simultaneous decisionmaking with respect to the household's consumption of the non-locational good $\mathrm{H}$, the locational good $\mathrm{L}$ and transportation $\mathrm{T}$, has been stated, use of simultaneous equation estimating techniques is required.

\section{EMPIRICAL ANALYSIS}

\section{Data Base}

The data base used for this study was originally collected for the Atlanta Area Transportation Study (AATS) in 1961 and for the 1960 Census of Housing $[5,14]$. The transportation study reflects household 
socioeconomic attributes and their travel behavior data of 280 small sub-areas called traffic zones within a large study area defined by a circumferential highway located, on the average, about ten miles from the central business district (See Figure 1). Tract data were obtained from the Census of Housing and were assigned to traffic zones on the bases of weights which were related to the degree of their spatial coincidence between zone and tract.

\section{Model Development}

There are four equations that constitute the consumer model which describes the household's attempt to satisfy its need for housing service flows. These are shown below:

(9) $\mathrm{H}_{\mathrm{k}}=\mathrm{f}\left(\mathrm{L}_{\mathrm{k}}, \mathrm{T}_{\mathrm{k}}, \mathrm{I}_{\mathrm{k}}, \mathrm{FS}_{\mathrm{k}}, \mathrm{LFP}_{\mathrm{k}}, \mathrm{R}_{\mathrm{k}}\right)$

(10) $\mathrm{L}_{\mathrm{k}}=\mathrm{f}\left(\mathrm{H}_{\mathrm{k}}, \mathrm{T}_{\mathrm{k}}, \mathrm{I}_{\mathrm{k}}, \mathrm{EMPD}_{\mathrm{k}}, \mathrm{R}_{\mathrm{k}}, \mathrm{SCTR}_{\mathrm{k}}\right)$

(11) $\mathrm{M}_{\mathrm{k}}=\mathrm{f}\left(\mathrm{A}_{\mathrm{k}}, \operatorname{LTS}_{\mathrm{k}}, \mathrm{FS}_{\mathrm{k}}, \mathrm{EMPD}_{\mathrm{k}}, \mathrm{I}_{\mathrm{k}}\right)$

(12) $\mathrm{T}_{\mathrm{k}}=\mathrm{f}\left(\mathrm{H}_{\mathrm{k}}, \mathrm{L}_{\mathrm{k}}, \mathrm{M}_{\mathrm{k}}, \mathrm{I}_{\mathrm{k}}\right)$

The model is also stratified into four income groups:

Class $1-\$ 0-\$ 3,999$ (average annual household income)

Class 2- $\$ 4,000-\$ 6,999$

Class $3-\$ 7,000-\$ 9,999$

Class $4-\$ 10,000$ and above

The endogenous variables are:

$\mathrm{H}_{\mathrm{k}}$ : The amount of the non-locational specific housing good used. It can be thought of as those attributes which relate to the housing unit itself: lot size, construction quality, age and size. Because there is no simple observable measure of these attributes, net residential density is used as a proxy measure for the non-locational specific housing good. The non-locational housing good is the reciprocal of the net residential density. In other words, a decrease in density indicates increased consumption of $\mathrm{H}$.

$L_{k}$ : The amount of the locational specific housing good used, and is defined by a vector of attributes which relate to the spatial location of the non-locational specific housing good $\left(\mathrm{H}_{\mathrm{k}}\right)$ within the metropolitan area. These attributes include distance from the central business district, neighborhood amenities and level of public service available. It is assumed that two readily available attributes of the locational specific good are suitable for use in the model. This is the distance of the traffic zone from the CBD and its sector. The internal study area is divided into eight sub-areas extending from the central business district (CBD) outward. These divisions are shown in Figure 1. The locational specific housing good $(\mathrm{L})$ is the reciprocal of traffic zone distance from the CBD (closer lo- 


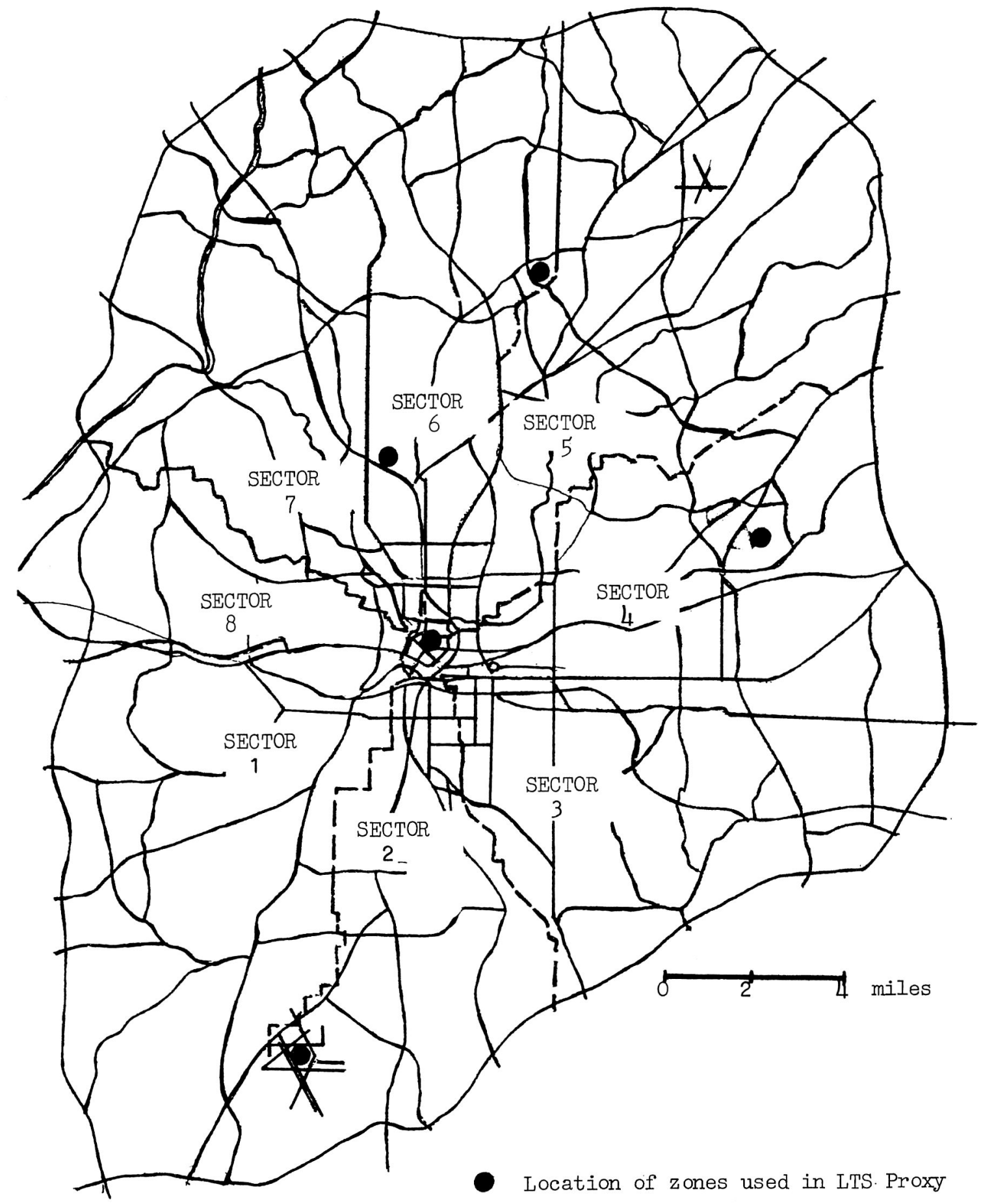

Figure 1. Internal Study Area and Its Sector Divisions 
cations to CBD mean larger values of L) while sector (SCTR) is a dummy variable used within the model itself. The use of the sector variable will allow the model to take into account the expected differences in the locational specific housing good with respect to direction as well as distance from a central point.

A basic assumption made relative to the use of proximity of traffic zone to the CBD concerns the "value" of proximity to the household. Because the CBD contains the region's largest variety of services and employment opportunities, it is assumed that households consider proximity to it as a positive "good."

A simple test of this assumption was made by regressing proximity to the city center as well as the log of density against value of single family housing. The results of this analysis were encouraging in that the expected signs of coefficients were obtained; both variables were statistically significant at the 5 percent level, with the regression itself having an $\mathrm{F}$ value of 9.5 and an $\mathrm{R}^{2}$ of .35 . As distance from the city center increased housing value declined, as densities increased housing values declined. ${ }^{6}$

$\mathrm{M}_{\mathrm{k}}$ : Mode choice, defined as the percent of all work trips taken by transit, and is a proxy measure of all household trips taken by transit.

$\mathrm{T}_{\mathrm{k}}$ : The amount of transportation used in the household's "production" of housing service flows, and is measured by the elapsed travel time for the journey to work, where auto and transit travel times are weighted by the number of work trips generated from zone of origin to all other zones.

The exogenous variables that enter the model which are expected to explain the size of the system determined variables are:

$I_{k}$ - Average income of households

$\mathrm{LFP}_{\mathrm{k}}$ - Labor force/population of households

$\mathrm{FS}_{\mathrm{k}}$ - Average family size of households

$R_{k}$ - Average monthly rents

$\mathrm{EMPD}_{\mathrm{k}}$ - Employment density at trip destination of households

$\mathrm{SCTR}_{\mathrm{k}}$ - One of eight sectors of the study area which provides locational specificity for households

$A_{k}$ - Average rate of household auto ownership

$\mathrm{LTS}_{\mathrm{k}}$ - A measure of the level of transit service available to households, proxied by the ratio of average travel time by auto from the household's residential traffic zone to other selected zones and of the average travel time by transit to those same zones. As transit service improves, the size of the LTS variable will increase. The destination zones selected for use include one in the 
central business district and four others which have high levels of employment. The spatial distribution of these zones is shown in Figure 1. Rationale for these zonal selections were based on the assumption that these zones, which have high concentrations of employment, if not high levels of transit service, would be the beneficiaries of general transit service improvements if they should occur.

An examination of the mean value of the variables used in the model can be useful in assessing whether or not intuitive judgment concerning their relative size, especially between income classes, is confirmed by the data. These values are shown in Table 1.

The data in the table does in fact confirm a priori judgments. The poorest households use the least amount of the non-locational specific housing good $(\mathrm{H})$, the greatest amount of the locational specific housing good $(\mathrm{L})$, reflecting the obvious centralization of poor near the core of the city, and have the highest amount of transportation input $(\mathrm{T})$ in the generation of housing service flows. It is also interesting to note

TABLE 1

Mean Value of Model Variables

\begin{tabular}{|c|c|c|c|c|c|}
\hline \multirow[b]{2}{*}{ Variable } & \multicolumn{5}{|c|}{ Mean Value } \\
\hline & All Zones & $\begin{array}{c}\text { Class } \\
\text { I Zones*** }\end{array}$ & $\begin{array}{l}\text { Class } \\
\text { II Zones }\end{array}$ & $\begin{array}{l}\text { Class } \\
\text { III Zones }\end{array}$ & $\begin{array}{c}\text { Class } \\
\text { IV Zones }\end{array}$ \\
\hline Income $(I)$ & 8476.70 & 3339.60 & 5802.10 & 8142.90 & 14823.00 \\
\hline $\begin{array}{l}\text { Non-Locational } \\
\text { Specific HSG Good (H) }\end{array}$ & .489 & .0717 & .375 & .431 & .897 \\
\hline $\begin{array}{l}\text { Locational } \\
\text { Snecific HSG }\end{array}$ & 3034 & 863 & 330 & 196 & 181 \\
\hline Transportation $(\mathrm{T})$ & 27.26 & 31.16 & 27.32 & 26.58 & 26.49 \\
\hline Mode Choice $(\mathbf{M})$ & .176 & .542 & .218 & .088 & .085 \\
\hline Level of Transit & & & & & \\
\hline Service (LTS) & .496 & .602 & .519 & .486 & .432 \\
\hline Rent ( R) & 105.97 & 55.72 & 80.75 & 108.65 & 158.94 \\
\hline Employment & & & & & \\
\hline Density (EMPD) & .220 & .185 & .218 & .192 & .272 \\
\hline Family Size (FS) & 4.04 & 4.69 & 4.23 & 3.86 & 3.76 \\
\hline Labor Force & & & & & \\
\hline Participation (LFP) & .422 & .374 & .429 & .433 & .419 \\
\hline Auto Ownership (A) & 1.50 & .555 & 1.22 & 1.48 & 1.90 \\
\hline Sector (SCTR) & 4.10 & 4.52 & 3.82 & 3.32 & 5.34 \\
\hline
\end{tabular}

*All zones except CBD, and Zones 92 and 113.

$* *$ Zonal class values are: Class I - $\$ 0-\$ 3,999$

Class II - $\$ 4,000-\$ 6,999$

Class III - $\$ 7,000-\$ 9,999$

Class IV - $\$ 10,000$ and above 
that the poorest households have a transit mode choice for the journey to work that is over six times as great as the most affluent income group.

\section{Model Results}

Assessing the impact of improving the level of transit service in the community as well as taking into account the simultaneous impact of changes of other critical variables such as income, rents, auto ownership and employment density, takes place in two steps. The first step provides the coefficient estimates (See Table 2) for the model variables calculated by using three stage least squares regression techniques [13]. Only the results for the unstratified version are reported.

The F-statistic for each equation is sufficiently large to reject the null hypothesis regarding significance of the regression. It is not possible, however, to reject the null hypothesis with respect to significance of size of variable coefficients in some instances. The use of the sector dummy variable, for instance, appears to be weak. Similar statistical results were obtained when the data was stratified. The smaller the number of observations within the income class, the less successful were the regression results.

While it may be possible, using the statistical model as it now appears, to examine the direct impact of income, for example, on the amount of the locational specific good (L) used by households, it is not possible to determine what effect a change in the level of transit service (LTS) will have on that same variable. In order to make this assessment it is necessary to change the structural model which has estimative statistical properties into a simulation version which does not have these properties. Because of this, it is more appropriate to discuss model results in terms of simulation tests which provide a convenient way of accounting for the full impact of changes in income, employment density and level of transit service available upon the system determined variables: $\mathrm{H}, \mathrm{L}$ and $\mathrm{T}$. The unstratified version of the model set up for simulation testing appears in Table 3.

\section{SIMULATION EXPERIMENTS}

\section{Improvement in the Level of Transit Service}

The first simulation test to be carried out deals with the impact of an improvement of the level of transit service and the system determined variables. These are summarized for all income classes in Table 4.

The generally implied trade-offs for the unstratified model seem to agree with a priori expectations. The impact of transit would tend to stimulate households to substitute locational for non-locational goods, keeping transportation about the same. If the dependent variables were interpreted literally it would mean that households would choose to live at higher densities, closer to the central business district, keeping transportation outlays about the same. 
TABLE 2

Regression Parameter Estimates All Zones

\begin{tabular}{|c|c|c|c|c|}
\hline Equation & $\begin{array}{c}\text { Independent } \\
\text { Variables }\end{array}$ & $\begin{array}{c}(\mathbf{B}) \\
\text { Coefficient } \\
\text { Estimates }\end{array}$ & $\begin{array}{l}(\mathrm{SD}) \\
\text { Standard } \\
\text { Error }\end{array}$ & $\mathrm{B} / \mathrm{SD}$ \\
\hline (1) $\mathrm{H}$ & $\begin{array}{l}\text { Constant } \\
\text { L } \\
\text { T } \\
\text { I } \\
\text { FS } \\
\text { LFP } \\
\text { R }\end{array}$ & $\begin{array}{l}3.311 \\
-.7207 \\
-.0467 \\
.0000503 \\
-.0406 \\
-3.645 \\
.00051\end{array}$ & $\begin{array}{l}.8130 \\
.2949 \\
.01715 \\
.0000176 \\
.0332 \\
.795 \\
.0022\end{array}$ & $\begin{array}{r}4.07 \\
-2.44 \\
-2.72 \\
2.85 \\
-1.21 \\
-4.59 \\
-.22\end{array}$ \\
\hline \multicolumn{2}{|c|}{$\begin{array}{l}\text { F Statistic } \\
\text { Degrees of Freedom }\end{array}$} & $\begin{array}{l}17.87 \\
(6,997)\end{array}$ & & \\
\hline (2) $\mathrm{L}$ & $\begin{array}{c}\text { Constant } \\
\text { H } \\
\text { T } \\
\text { I } \\
\text { EMPD } \\
\text { R } \\
\text { S1 } \\
\text { S2 } \\
\text { S3 } \\
\text { S4 } \\
\text { S5 } \\
\text { S6 } \\
\text { S7 }\end{array}$ & $\begin{array}{c}-.6210 \\
-.6950 \\
.0454 \\
.0000573 \\
-.8665 \\
-.00334 \\
.0737 \\
-.368 \\
.0911 \\
.0960 \\
.1669 \\
.2328 \\
.2511\end{array}$ & $\begin{array}{l}.4077 \\
.2092 \\
.0125 \\
.000019 \\
.2728 \\
.0018 \\
.115 \\
.1099 \\
.142 \\
.108 \\
.1156 \\
.1240 \\
.1480\end{array}$ & $\begin{array}{r}-1.52 \\
-3.32 \\
3.64 \\
3.05 \\
3.18 \\
-1.85 \\
.64 \\
.33 \\
.64 \\
-.89 \\
1.44 \\
1.88 \\
1.70\end{array}$ \\
\hline \multicolumn{2}{|c|}{$\begin{array}{l}\text { F Statistic } \\
\text { Degrees of Freedom }\end{array}$} & $\begin{array}{c}5.21 \\
(12,997)\end{array}$ & & \\
\hline (3) $\mathrm{T}$ & $\begin{array}{l}\text { Constant } \\
\text { H } \\
\text { L } \\
\text { I } \\
\text { M }\end{array}$ & $\begin{array}{l}27.60 \\
.7029 \\
-20.00 \\
-.0000769 \\
34.28\end{array}$ & $\begin{array}{l}1.67 \\
1.57 \\
5.29 \\
.000141 \\
7.06\end{array}$ & $\begin{array}{r}17.56 \\
.48 \\
-3.79 \\
-5.47 \\
4.86\end{array}$ \\
\hline \multicolumn{2}{|c|}{$\begin{array}{l}\text { F Statistic } \\
\text { Degrees of Freedom }\end{array}$} & $\begin{array}{l}5.64 \\
(4,997)\end{array}$ & & \\
\hline (4) $\mathrm{M}$ & $\begin{array}{l}\text { Constant } \\
\text { A } \\
\text { LTS } \\
\text { FS } \\
\text { EMPD } \\
\text { I }\end{array}$ & $\begin{array}{l}-.3587 \\
-.2162 \\
.8090 \\
.0737 \\
.3842 \\
.00000640\end{array}$ & $\begin{array}{l}.0729 \\
.0234 \\
.1167 \\
.0089 \\
.0609 \\
.00000304\end{array}$ & $\begin{array}{r}-4.92 \\
-9.25 \\
6.94 \\
8.28 \\
6.31 \\
2.11\end{array}$ \\
\hline $\begin{array}{l}\text { F Statis } \\
\text { Degrees }\end{array}$ & dom & $\begin{array}{l}48.22 \\
(5,997)\end{array}$ & & \\
\hline
\end{tabular}

It is not sufficient, however, to examine aggregates in this instance, because stratification of the data into income classes, reveals that consideration of the unstratified model can also mask significant divergences in household behavior. This is evident when considering the difference in the model's response between Income Class I (households earning 
TABLE 3

Simulation Version of Behavioral Model Unstratified Model

\begin{tabular}{cllcc}
\hline \multirow{2}{*}{$\begin{array}{c}\text { Independent } \\
\text { Variables }\end{array}$} & \multicolumn{4}{c}{ Dependent Variables } \\
\cline { 2 - 5 } & $\mathrm{H}$ & $\mathrm{L}$ & $\mathrm{T}$ & $\mathrm{M}$ \\
\hline Constant & 2.353 & -0.779 & 32.54 & -0.359 \\
I & 0.0000459 & 0.0000175 & -0.000175 & 0.0000064 \\
FS & -0.1318 & 0.1059 & 0.3163 & 0.0737 \\
LFP & -3.293 & 1.144 & -25.20 & - \\
R & -0.000798 & -0.00147 & 0.0289 & - \\
EMPD & -0.583 & 0.0618 & 11.53 & 0.384 \\
S1 & 0.0074 & 0.036 & -0.716 & - \\
S2 & -0.00372 & -0.0180 & 0.357 & - \\
S3 & 0.0092 & 0.00445 & -0.885 & - \\
S4 & 0.00970 & 0.0469 & -0.932 & - \\
S5 & 0.0169 & 0.0816 & -1.62 & - \\
S6 & 0.0235 & 0.114 & -2.26 & - \\
S7 & 0.0254 & 0.123 & -2.44 & - \\
A & 0.279 & -0.273 & -1.751 & -216 \\
LTS & -1.043 & 1.022 & 6.554 & 0.809 \\
\hline
\end{tabular}

TABLE 4

Summary of Simulation-All Income Classes

Experiment I: $10 \%$ LTS Increase

\begin{tabular}{llll}
\hline \multirow{2}{*}{$\begin{array}{l}\text { System Affect As } \\
\text { Percent of Mean }\end{array}$} & \multicolumn{3}{c}{ System Variable } \\
\cline { 2 - 4 } & $\mathrm{H}$ & $\mathrm{L}$ & $\mathrm{T}$ \\
\hline All Zones & $-10.6 \%$ & $+16.8 \%$ & $+1.2 \%$ \\
Income Class I: & -85.1 & +44.1 & -4.5 \\
Income Class II: & -4.2 & -4.2 & +2.8 \\
Income Class III: & -3.1 & +0.04 & +3.6 \\
Income Class IV: & -1.4 & +0.33 & +2.1 \\
\hline
\end{tabular}

less than $\$ 3,000$ ) and the remaining three income classes. It is interesting to note that increases in the level of transit lead to a reduction in the size of $\mathrm{T}$ for low income households while it increases the size of $\mathrm{T}$ for households in the other three income classes. This result can perhaps be explained by the fact that low income households, since they are already heavy transit users anyway, are not induced to switch from an auto mode to the slower transit mode by the improvements in the level of transit service. They merely experience a reduction in travel time. Upper income households, on the other hand are induced to switch modes in proportionately greater numbers giving rise to increases in travel time. The increase in the amount of the locational specific housing good (L), used by low income households is also an indication that they value good transit service and are willing to live at higher densities and much closer in to the city center in order to get to the access they 
apparently need. The highly elastic response of this lowest income class completely dominates the aggregate data results. Simulation results indicate that the three remaining income classes have a fairly inelastic response to improvements in the level of transit service. While there may be a slight movement toward higher residential density and greater proximity to the center city, this movement is hardly perceptible. For households in income class II, the improvement in transit service probably means an opportunity to escape a little further toward suburbia, but living at somewhat higher densities.

\section{Special Simulation Test}

Households usually experience a "package" of changes in the size of some of the exogenous variables. For example, rents, auto ownership, as well as income can be changing simultaneously. A simulation exercise was carried out to determine if results would be consistent with what has occurred with respect to urban residential patterns. This experiment took as a package of changes the following:

1. 10 percent increase of income

2. 10 percent decrease in employment density

3. 10 percent increase in rents

4. 10 percent increase in auto ownership

5. No change in the level of transit service available.

This "package" of changes is arbitrarily chosen although it does recognize the general trend in size of these variables since the early 1960's. The reason for allowing no change in the level of transit service is to keep its influence on results neutral. A more realistic assumption would be to have it decrease in size.

It should be noted that improved transit could reduce auto ownership and increase employment densities. For the purposes of this paper however, auto ownership and employment densities are taken as exogenously determined. Auto ownership is influenced by a large number of factors including income, relative prices and operating costs. I have assumed that all of these forces, especially in the 1960's, outweigh the direct influence of improvements in transit service on decreasing auto ownership. A similar assumption was used with respect to employment density. A large number of factors influence employment density-technology of production, price of land, character of industry, accessibility to inputs and markets, etc. Again, all of these forces were taken to outweigh the direct influence of improvements in transit service on increasing employment density. A summary of results for this simulation experiment is in Table 5.

The influence of this "package" of changes of these selected exogenous variables reinforces urban dispersal patterns and enables all households to live at lower densities. All households, regardless of income class, use more $\mathrm{H}$ and less $\mathrm{L}$. The two lowest income groups, however, experience slight increases in the amount of transportation used. These 
TABLE 5

Summary Results of Package Simulation Test

\begin{tabular}{ccccc}
\hline $\begin{array}{c}\text { Income } \\
\text { Group }\end{array}$ & $\begin{array}{c}\text { System } \\
\text { Variable }\end{array}$ & $\begin{array}{c}\text { Mean Value } \\
\text { of System } \\
\text { Variable }\end{array}$ & $\begin{array}{c}\text { Total } \\
\text { System } \\
\text { Affect }\end{array}$ & $\begin{array}{c}\text { System Affect } \\
\text { As Per Cent of } \\
\text { Mean }\end{array}$ \\
\hline Unstratified & $\mathrm{H}$ & .489 & +0.085 & $+17.4 \%$ \\
Household & $\mathrm{L}$ & .303 & -0.043 & $-14.2 \%$ \\
Group & $\mathrm{T}$ & 27.26 & -0.359 & $-1.3 \%$ \\
Income Class & $\mathrm{H}$ & 0.717 & +0.010 & $+13.9 \%$ \\
I & $\mathrm{L}$ & 0.863 & -0.200 & $-23.2 \%$ \\
$(\$ 0-\$ 3,999)$ & $\mathrm{T}$ & 31.16 & +0.230 & $+0.7 \%$ \\
Income Class & $\mathrm{H}$ & 0.375 & +0.097 & $+25.9 \%$ \\
II & $\mathrm{L}$ & 0.336 & -0.090 & $-26.8 \%$ \\
$(\$ 4,000-\$ 6,999)$ & $\mathrm{T}$ & 27.32 & +0.387 & $+1.4 \%$ \\
Income Class & $\mathrm{H}$ & 0.464 & +0.108 & $+24.9 \%$ \\
III & $\mathrm{L}$ & 0.196 & -0.006 & $-3.1 \%$ \\
$(\$ 7,000-\$ 9,999)$ & $\mathrm{T}$ & 36.58 & -2.10 & $-7.9 \%$ \\
Income Class & $\mathrm{H}$ & 0.897 & +0.208 & $+23.2 \%$ \\
IV & $\mathrm{L}$ & 0.181 & -0.004 & $-2.2 \%$ \\
$(\$ 10,000+)$ & $\mathrm{T}$ & 36.49 & -0.387 & $-1.5 \%$ \\
\hline
\end{tabular}

Note: This package of simulation changes includes 10 per cent increases in income, rents, and auto ownership, a 10 per cent decrease in employment density, with no change in the level of transit service available.

findings are generally consistent with well documented empirical evidence.

\section{SUMMARY}

Understanding the caveats that must be employed with respect to measurement crudeness, it is possible to state that the results of empirical testing of the model do indicate that initial assumptions made with respect to using the concept of housing service flows are reasonable, that much of the model's operating results are statistically significant, and that simulation tests generally tend to support a priori expectations. There are, of course, exceptions.

Results of the initial simulation indicate the general inability of improvements in the level of transit service (LTS) to significantly shift household residential locational patterns such that proximity to the CBD is increased (more consumption of the locational specific housing good, L). This result emerges from the income stratified versions of the model but is masked when examining aggregated household behavior through the use of the unstratified model.

The results of the simulation test which allows for changes in income rents, auto ownership, and employment density but no change in the level of transit service, provides a more realistic examination of the effect of current trends in the size of these variables upon the household's use of $\mathrm{H}, \mathrm{L}$, and T. In all variations of the model, this "package" of 
changes increased the household's consumption of the non-locational specific housing good $(\mathrm{H})$, and decreased consumption of the locational specific housing good (L), with relatively modest shifts in the household's use of transportation ( $\mathrm{T})$. If we compare the results of both simulation experiments, it appears that improved transit will tend to shift residential locational patterns in the direction of greater proximity to the central city, it is uncertain that it will be sufficiently large to offset those forces stimulating residential dispersal.

Another interesting result of model operation was the extent of the influence of level of transit service on mode choice. While it was assumed that improvements in the level of transit service would cause increases in those who chose the transit mode, it was only of concern because of its expected influence upon $\mathrm{H}, \mathrm{L}$, and $\mathrm{T}$. Its direct impact upon mode choice, however, is greater relative to what might have been expected from reviewing the results obtained by John Kain's work [8] on household residential choice and travel behavior. He found that increases in the use of transit would be relatively inelastic with respect to improvement in the level of transit service. His elasticity figure was $1 / 3$ while the elasticity measure for Income Class I, II, III, and IV are 1.11, $0.98,2.01$, and 2.04 respectively. The elasticity coefficient for the unstratified version of the model is 2.27 . These figures indicate the mode choice response to improvements in the level of transit service may be greater than is generally presumed. It should be pointed out, however, that even enormous improvements in the transit service available would still leave the majority of the higher income households still using autos for the journey to work. A 100 per cent increase in the level of transit service available to households in Income Class IV, for example, would shift the mode choice variable from 8.5 percent to approximately 25.9 percent. $^{7}$

There are interesting policy questions concerning public investment programs which affect transit and auto usage. Careful assessment of probable impact on patronage of the investment programs should be made. The Metropolitan Rapid Transit Authority has embarked on a multi-billion transit improvement program in the Atlanta area. While substantial mode switch may occur, the overwhelming portion of trip making (trip making for the journey to work) will not be by transit. Based on the results of the income stratified models, the improvements in transit will have little impact upon the mode choice of the upper income households. The nature of the investment programs being proposed while not solely geared to encourage transit use by these upper income households, getting these suburban commuters out of their cars is a major program objective.

1See Mills [1972, p. 101]

2See UMTA [1973, pp. 13-14].

3See Mills [1971, p. 136].

4See Getz [1975, pp. 57-74].

\section{FOOTNOTES}

5Other studies with this finding include Cebula (1974, pp. 876-879) and Rogers (1968) 6See Davis [1973, pp. 101-114].

7See Davis [1973, p. 183]. 


\section{REFERENCES}

[1] Alonso, William. Location and Land Use (Cambridge, Massachusetts: Harvard University Press, 1964).

[2] American Public Transit Association, Transit Fact Book, 1974-1975, March, 1975.

[3] Cebula, Richard, "The Tiebout Hypothesis: An Analysis According to Race, Age, and Sex", Journal of the American Statistical Association, 69 (1974), pp. 876-9.

[4] Davis, Sid. Household Consumption of Housing Service Flows in Atlanta, Georgia (Atlanta, Georgia: Georgia State University, Unpublished dissertation. 1973).

[5] Georgia, State Highway Department of. Atlanta Area Transportation S.tudy. 1970.

[6] Getz, Malcolm. The Incidence of Rapid Transit in Atlanta, (Atlanta, Georgia: Atlanta University, 1973).

[7] Getz, Malcolm, "A Model of the Impact of Transportation Investments on Land Rents", Journal of Public Economics 4 (1975), pp. 57-74.

[8] Kain, John F. A Multiple Equation Model of Household Locational and Tripmaking Behavior (Santa Monica, CA: Rand Corporation, 1962).

[9] Mills, E. S. Urban Economics, (Glenview, Illinois: Scott, Foresman and Company, 1972). p. 101.
[10] Studies in Structure of the Urban Economy (Baltimore, Maryland: The Johns Hopkins Press, 1971).

[11] Muth, Richard. Cities and Housing: The Spatial Pattern of Urban Residential Land Use (Chicago, Illinois: University of Chicago Press, 1969).

[12] Rogers, Andrei. Matrix Analysis of Interregional Population and Distribution (Berkeley and Los Angeles, CA: University of California Press, 1968).

[13] Stroud, A., Fellner, A. and Chau, L. C. Program Write-Up: Computing Two and Three Stage Least Squares Estimates and Association Statistics (Madison, Wisconsin: University of Wisconsin, Social System Research Institute, 1967).

[14] U.S. Bureau of Census, United States Census of Housing, 1960, (Washington, D.C.: U.S. Government Printing Office, 1962).

[15] Urban Mass Transportation Administration, U.S. Department of Transportation. Metropolitan Atlanta Rapid Transit Authority. Final Environmental Statement, March 1973.

[16] U.S. Congress, Federal-Aid Highway Act of 1956, June 29, 1956, Public Law 84-627.

[17] U.S. Congress, Urban Mass Transportation Assistance Act, October 15, 1970. Public Law 91-190. 